\title{
A CIVIL SUCCESS: SAVING SZÁDVÁR
}

\section{János Dobos - VikTor Gál - VikTória P. Horváth}

Hungarian Archaeology vol. 9 (2020), Issue 1, pp. 71-76, https://doi.org/10.36338/ha.2020.1.8

Our community, the "Friends for Szádvár Association" (henceforth: Association) was born in 2006, as an internet forum connecting castle enthusiasts to save one of our decaying medieval castles. The choice of the founding members fell on Szádvár, in the municipality of Szögliget, in Borsod-Abaúj-Zemplén County. Although in terms of its area Szádvár is the largest castle in Hungary, it remained almost unknown to the broader public as it is situated at the former border zone - it was closed to the public, and the ruins were also inaccessible, overgrown by vegetation (Fig. 1). This paper introduces the project of the Association and our results, and also tries to illuminate the questions how a community archaeology program started round fifteen years ago, and what are the problems to be faced by anyone who wishes to set out on a similar path.

The purpose of the Association was twofold: on the one hand, to save the castle of Szádvár - excavate and conserve the ruins and their heritage values -, contributing to the preservation of built heritage, and on the other hand to mobilize the locals living in the neighbourhood of the castle and promote the site as a local attraction. Creating a tourism destination from the castle, could potentially contribute to local tourism development generating an ever-increasing source of income for local services and hosts. Without the cooperation and support of local institutions, government authorities, volunteers and the locals, the Association would not have been able to realize this program. We organize three volunteer events around the year, among which the one week-long excavation in the summer season is the most popular, supervised by the staff of the Herman Ottó Museum in Miskolc. Each year, there are about 50-60 participants, excavating in 5-8 trenches.

In 2010-2017, 45 trenches were excavated, covering an approximately $620 \mathrm{sq}$ metres large area (Fig. 2). The excavation of test trenches prior to the conservation works coordinated by the Association, as well as in other places inside the ruin, helped to reconstruct the building history of the castle (which is, however, still not known in its entirety), as well as the extent and function of its rooms (Fig. 3). Due to the efforts of volunteers, a large number of 16 th -17 th century finds could be collected and were inventoried in the museum collection. These objects - including the tiles of collapsed stoves, ovens and the remains of an open hearth of the 17 th century kitchen - represent many aspects of the everyday life of the castle. There has been a small local exhibition set up, which allows our visitors to see part of the conserved finds, in case of interest.

In the framework of preventive excavations (conducted in connection to the National Castle Resto-

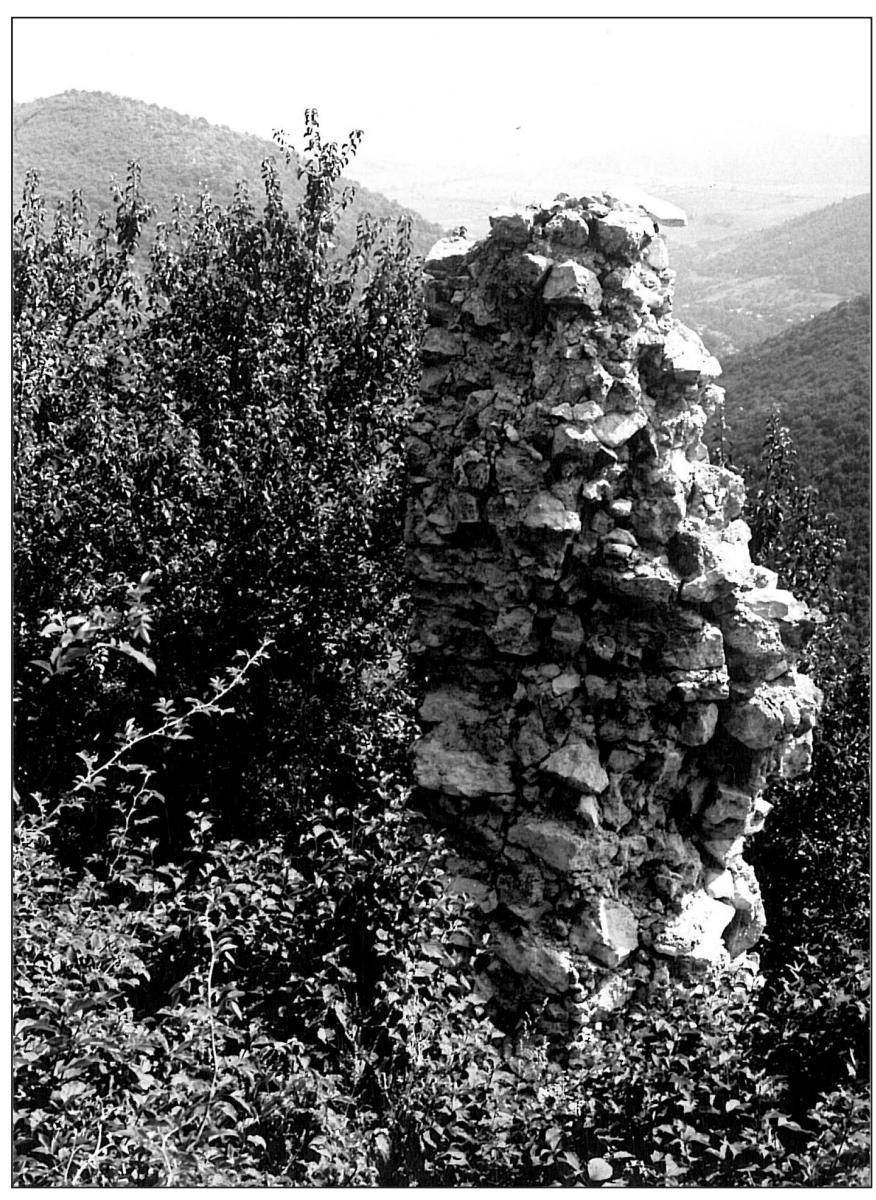

Fig. 1. The ruins of Szádvár

(Herman Ottó Museum, Photo and Negative Archive, 23495) 
János Dobos - Viktor Gál - Viktória P. Horváth • A Civil Success: Saving Szádvár

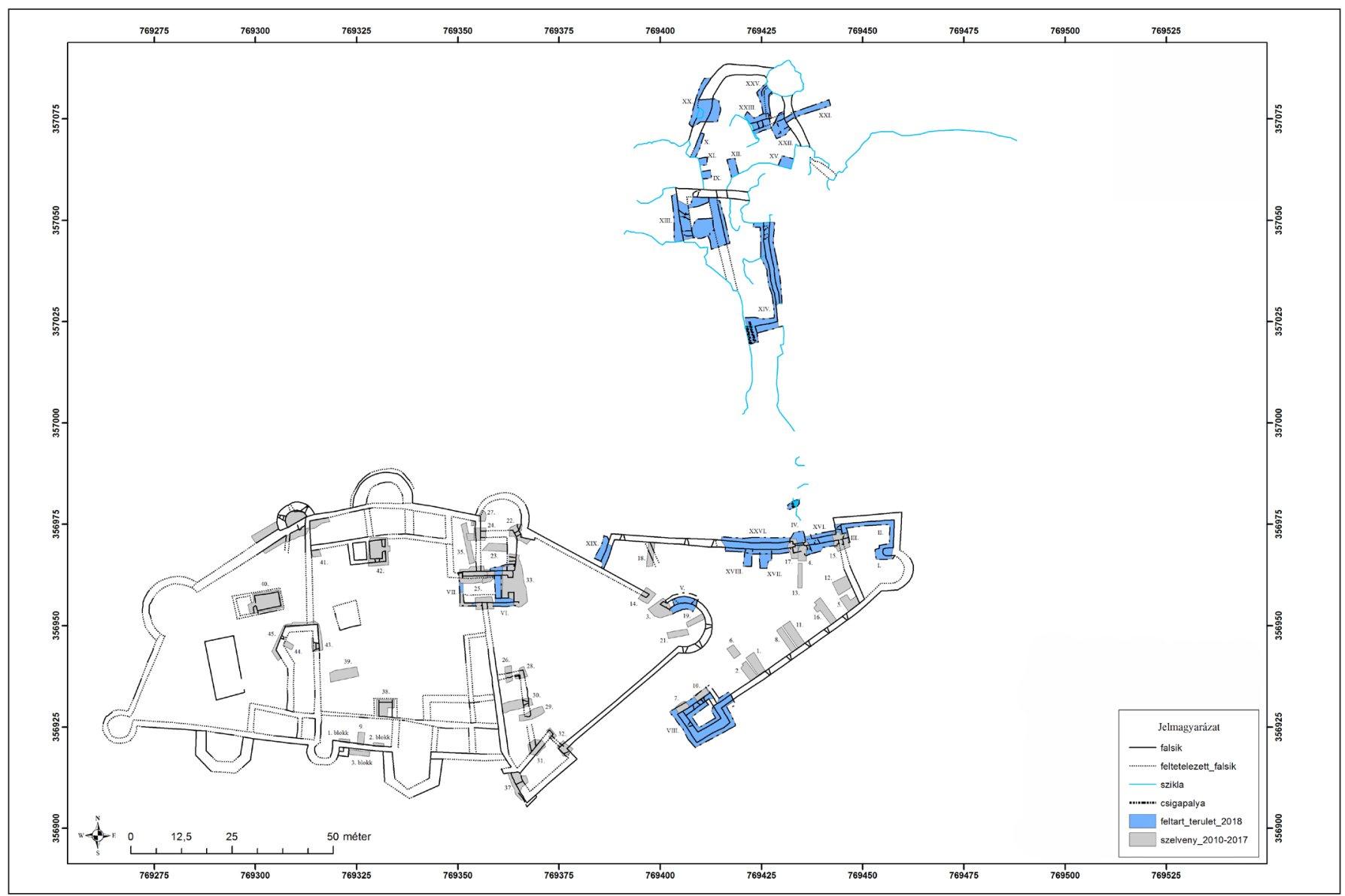

Fig. 2. Comprehensive map of the excavation, 2019 (Herman Ottó Museum)

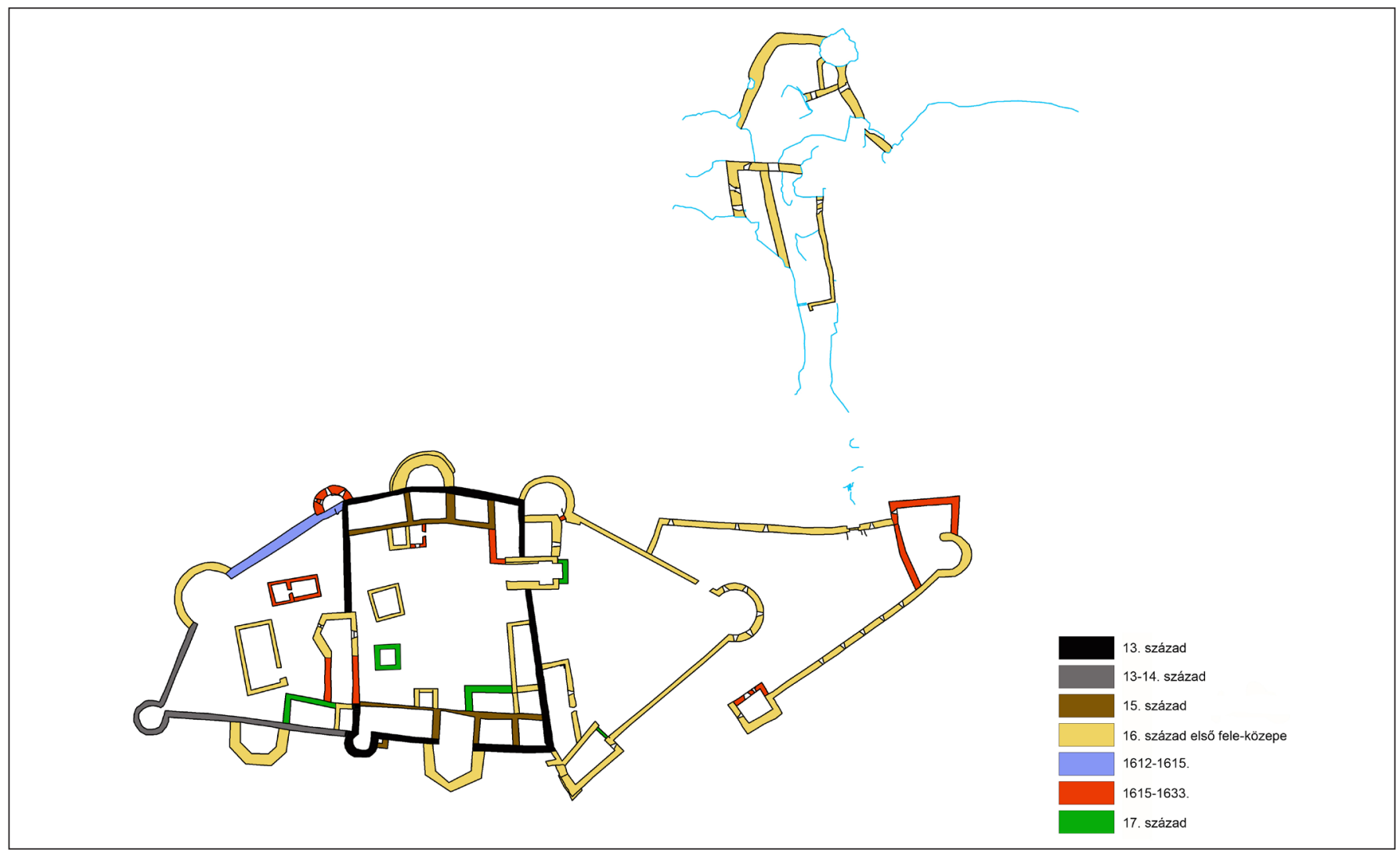

Fig. 3. A map of hypothetical periodization, 2019. Black: 13th c.; grey: 13-14th. c.; brown: 15th c.; yellow: first half and middle of the 16th c.; blue: 1612-1615; red: 1615-1633; green: 17th c. (Herman Ottó Museum) 
ration Program), an additional area of 720 sq metres were excavated in 2018. This excavation focused primarily on the area of the outer bailey, which was situated on the north side of the castle hill. Previously unknown - and even unexpected - details of the construction of the castle were brought to light. Following the four months long intensive project which also extended to the east part of the inner bailey and to the gate tower - a picture of a multipart defensive system emerged, dating from the second third of the 16th century and reflecting a consistent architectural concept. The pedestrian gate of the outer bailey and the path of the so called "elevator", - mentioned for the first time in 1570 -, were identified, which allowed for the reconstruction of the late medieval transport system (Fig. 4).

It has been an openly declared goal of the Association to attract more and more visitors to the events and convince them to join as volunteers and even become members of the Association. There is no business enterprise, or any for-profit organization providing financial support for the project, thus, cooperation was inevitable from the very start. We successfully negotiated with the Herman Ottó Museum in Miskolc, the Municipality of Szögliget, the current heritage protection authorities, the owner and manager of the area, the Directorate of the Aggtelek National Park, as well as with other civil associations. Some of our partners provide professional assistance to reach our goals, others contribute occasionally with donations, and others bring participants to our programs - in return, our volunteers also assist these organisations.

The question arises, what makes this initiative successful and sustainable. First of all, Szádvár was a fortunate choice - the ambiance of the place definitely played a part, i.e. the fact that it is a huge and significant castle, and an almost unknown site, hiding in the woods of the national park, in a wonderful environment, distant from everything. Leaving behind the busy towns, with all their amenities, is itself attractive from the point of view of our modern lifestyles. On another note, there is no doubt that the initiators and the first volunteers were coming from those circles, which cultivate a genuine interest in castles, ruins and

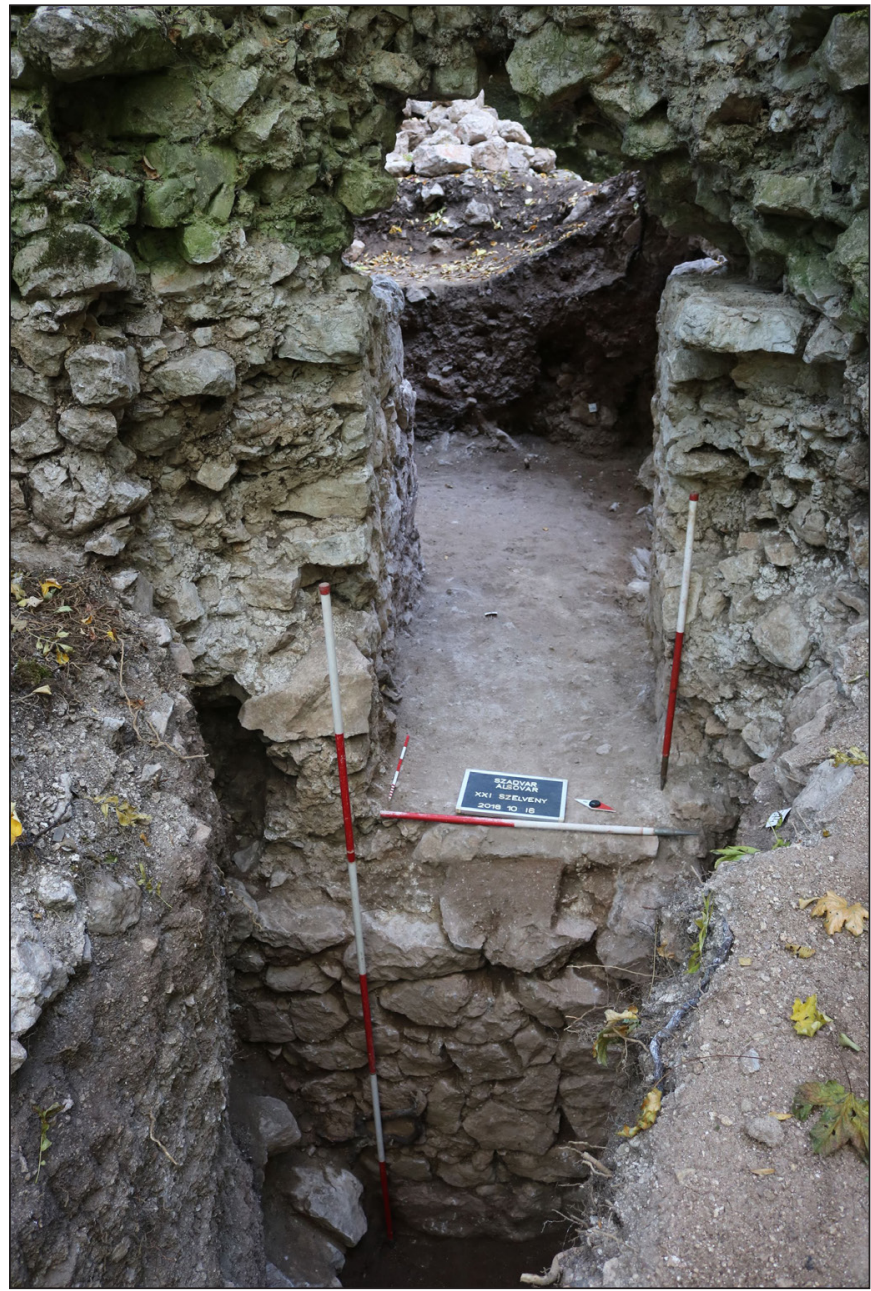

Fig. 4. Szádvár - Lower Castle, view from the pedestrian gate, 2018 (Herman Ottó Museum)

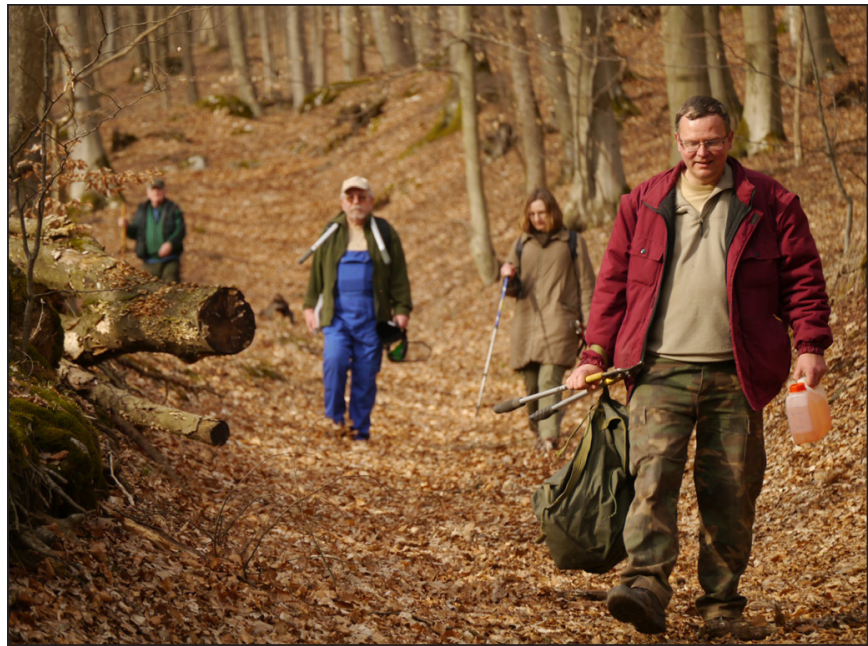

Fig. 5. At the end of a hard day (photo by the Friends for Szádvár Association) objects of cultural heritage. It is important, however, that in the early years all their efforts were focused on cleaning the ruins from the trees, bushes and surface vegetation and the first excavations could take place only three years after the Association was created (Fig. 5).

The archaeological fieldwork and excavation during the summer season clearly had a significant impact: they generated interest and helped to keep the volunteers involved. One would ask, however: "why vol- 


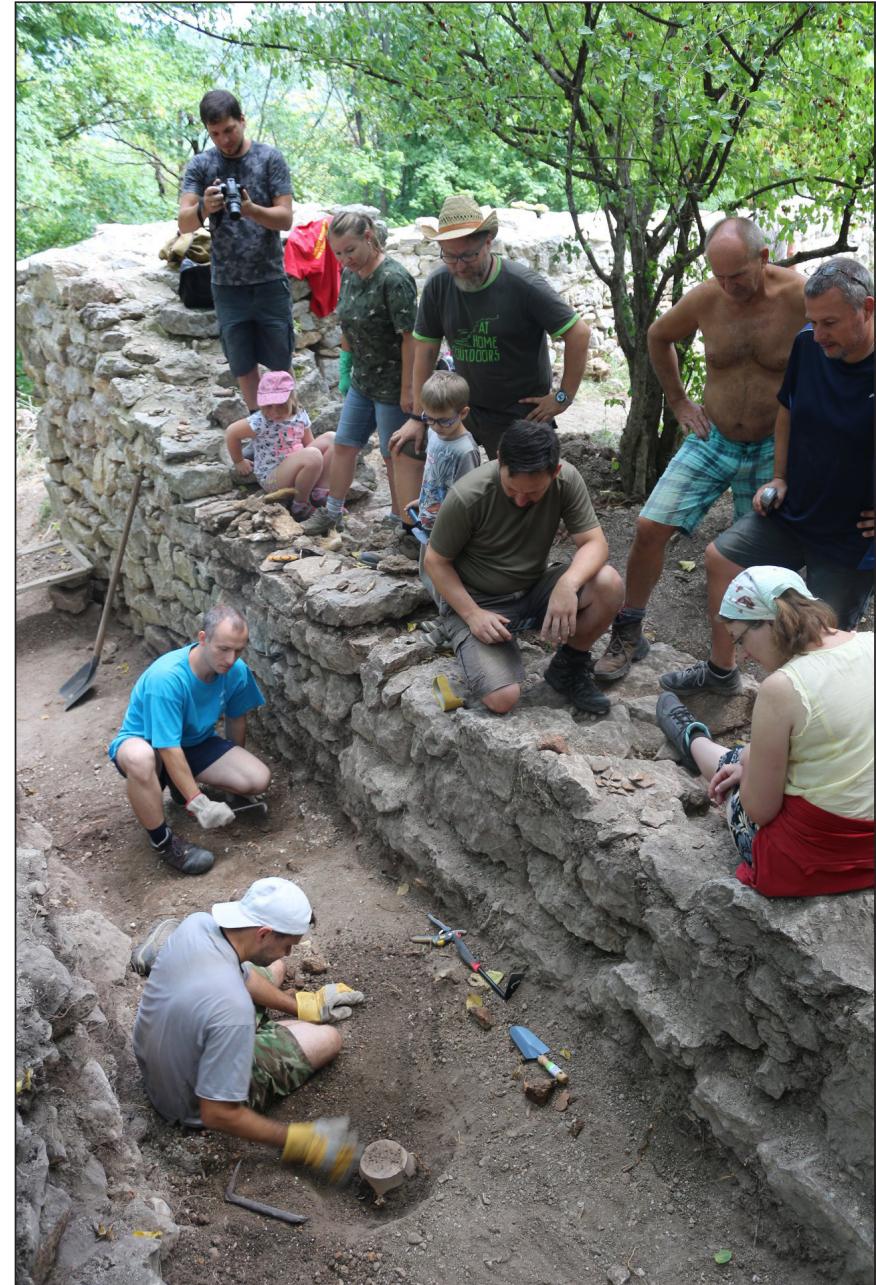

Fig. 6. Volunteers on the Castle Saving Week (photo by the Friends for Szádvár Association)

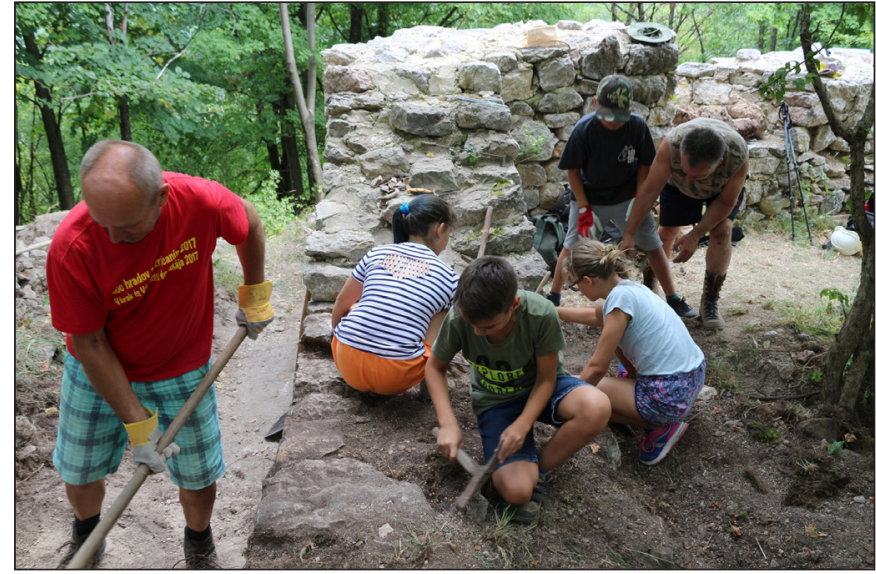

Fig. 7. Volunteers on the Castle Saving Week (photo by the Friends for Szádvár Association)

unteer as an "archaeologist?" Beyond the sheer act of discovery, truffle finding, or the idea of "everyone is an archaeologist at heart", the most important motivation for volunteers must be the instinct of doing something good by contributing to the preservation of our common cultural heritage (Figs 6-7). This clearly amplifies and satisfies also the need to belong to a community. While organizing our events, community building became more and more important, along with professional trainings for the public as we also invite experts presenting their research, including archaeologists, architects from different museums and castles.

The feedback we have received is, however, polarized. Institutions and professional organiza-
us with the Podmaniczky Prize, the Károly Kós Prize tions involved in heritage protection already awarded us with the Podmaniczky Prize, the Károly Kós Prize and the Gyula Forster Commemorative Medal. The Municipality of Szögliget awarded the "Pro Szögliget" plaquette and a diploma to our organization. In some cases, however, our volunteers reported that their work has been labelled as "hobby archaeology" and "truffle finding", which can be, apparently, very demotivating. Keeping motivation is, nonetheless, crucial, since the Association does not have financial support, and - supervised by an archaeologist - volunteers sacrifice their own free time.

Enthusiasm, as a precondition of this motivation, has, however, another effect. Volunteers may falsely think that it is possible to become a self-taught archaeologist, without professional training, and that they are also able to make professional decisions. Thus, the arising conflicts have to be carefully managed and everyone should keep in mind that it is not the volunteers, who coordinate the professional work, even though the project might be readjusted occasionally by the archaeologists, in line with what the volunteers might suggest as a matter of interest.

To this date, the primary forum of recruiting and involving volunteers is the internet and the social media. This is where our events are being organized, therefore, it is of extreme importance to know about those opportunities where we can promote our project. During the years, we created our own webpage, social media sites and video channel to raise the attention of potential volunteers, inviting them to join us. In connection to this, we observed that beyond the circles of castle enthusiasts it is worthwhile to communicate and advertise our work among hikers, nature enthusiasts, gastro connoisseurs, or other interest groups, since participation does not depend on a strictly historical interest. The questionnaire concerning our activities revealed that many people are motivated simply by the opportunity of volunteering, of discover dis- 


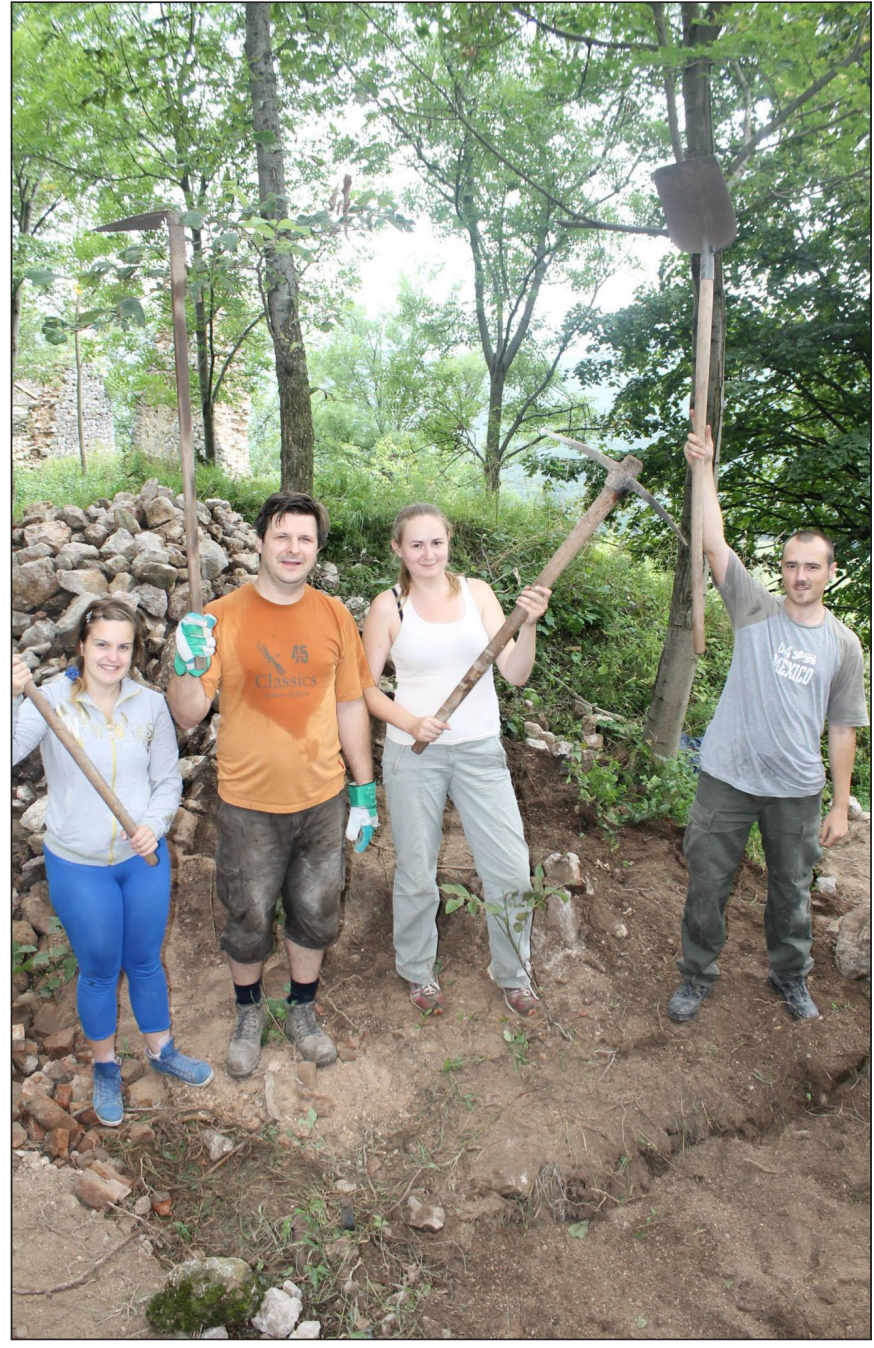

Fig. 8. Volunteers on the Castle Saving Week (photo by the Friends for Szádvár Association)

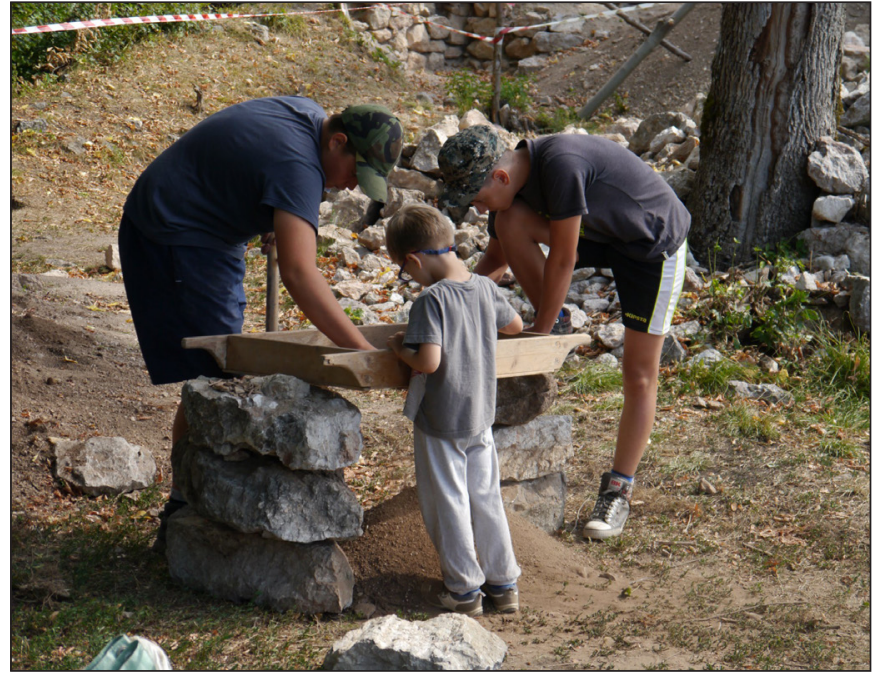

Fig. 9. Volunteers on the Castle Saving Week (photo by the Friends for Szádvár Association)

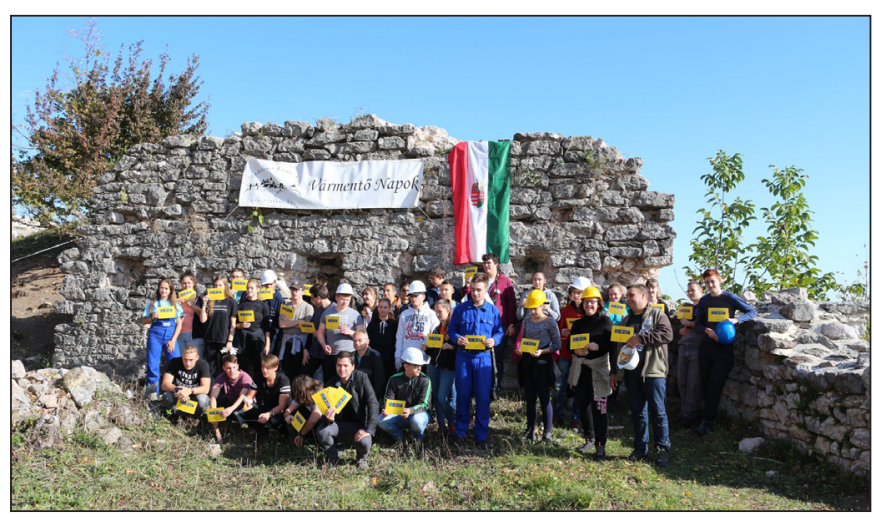

Fig. 10. Recurrent visitors of the Castle Saving Week: students of the Hild József High School (photo by the Friends for Szádvár Association)

covering the neighbourhood, just as well as by learning about the medieval history of the castle. It is also an important detail of cooperation in connection to social media, that we pay attention to publish only photos and videos about the work, which do not violate professional interests in general, i.e. the publication rights of the archaeologist, or of the developer.

Our results, the aforementioned awards and our continuous efforts to apply for funding to cover conservation related and operative costs culminated in the project realized in the National Castle Program, as Szádvár also made it to the list of funded projects. At last, this brought the media coverage the founders set out to achieve in 2006. However, it does not mean the end of neither the "Friends for Szádvár", nor the community archaeology project, as the scope of the National Castle Program covers only the previously excavated fragments of the castle area, and sustainable operation and management would not be possible without the volunteering activities (Figs 8-9).

It is our sincere hope that the now 15 years old enthusiasm - represented by an ever-changing group of volunteers - will stay with us to continue the work year by year, involving more and more people in discovering and saving our cultural heritage. In 2020, all participants should agree to the principles of sticking to an honest and open code of conduct and to the appropriate use of resources in order to maintain effective cooperation. Fortunately, there are other positive examples from around the country, which demonstrate that professional archaeologists can rely on the physical and intellectual capacities of civil enthusiasts, who in turn may profit from this participation in various ways. Thus, we should not turn away from one another, but seek solutions to realize our common goal to protect our cultural heritage (Fig. 10). 
János Dobos - Viktor Gál - Viktória P. Horváth • A Civil Success: Saving Szádvár

RECOMMENDED READINGS

Détshy, M. (1969). Egy ismeretlen magyar vár - Szádvár. Herman Ottó Múzeum Évkönyve 8, $143-186$.

Fejes, E., Hancz, E., Kovács, L., Kőnig, F., László, J., et al. (2014). Szádvár: Rekonstrukciós elképzelések. Szögliget: Civertan Grafikai Stúdió, Szádvárért Baráti Kör.

Gál-Mlakár, V. (2011). Szögliget-Szádváron végzett állagvédelmi munkák módszerei és tapasztalatai. In Terei Gy., Kovács Gy., Domokos Gy., Miklós Zs. \& Mordovin M. (ed.), Várak nyomában - Tanulmányok a 60 éves Feld István tiszteletére (pp. 63-72). Budapest: Castrum Bene Egyesület, Civertan Grafikai Stúdió.

Gál, V. (2016). Adatok Szádvár 1567-es ostromához. In: Kósa P. (ed.), Várak, kastélyok, templomok: Évkönyv 2016 (pp. 80-85). Kökény: ZIMédia.

Gál, V. (2019). Szögliget-Szádvár 2018. évi régészeti kutatásának eredményei. Castrum 22 (1-2), 189-212.

Gál, V. \& Kelemen, B. Z. (2014). Ledentu 3D-ben - Szádvár tömegrekonstrukciós kísérletének forrásai és látványvilága. Archeologia - Altum Castrum Online, A Magyar Nemzeti Múzeum Visegrádi Mátyás Király Múzeumának Középkori Régészeti Online Magazinja. http://archeologia.hu/content/archeologia/257/ szadvaar-kelemen-gal-2.pdf Accessed Feb 07, 2020.

Kelemen, B. Z. (2017). Állagmegóvási munkák Szádváron. In Kósa P. (ed.), Várak, kastélyok, templomok: Évkönyv 2017 (pp. 110-111). Kökény: ZIMédia.

Szádvárért Baráti Kör (2016). Egy civil sikertörténet. Szádvár megmentése. Szögliget: Szádvárért Baráti Kör. 